\title{
Molecular mapping and intra-cluster recombination between anthracnose race-specific resistance genes in the common bean differential cultivars Mexico 222 and Widusa
}

\author{
Cristina Rodríguez-Suárez $\cdot$ Juan José Ferreira • \\ Ana Campa $\cdot$ Astrid Pañeda $\cdot$ Ramón Giraldez
}

Received: 17 October 2007 / Accepted: 8 January 2008 / Published online: 22 January 2008

(C) Springer-Verlag 2008

\begin{abstract}
Resistance to races 19, 31, 38, 65, 73, 102, and 449 , of the pathogenic fungus Colletotrichum lindemuthianum (anthracnose) was evaluated in $\mathrm{F}_{3}$ families derived from the cross between the anthracnose differential bean cultivars Mexico 222 (resistant to races 19, 31, and 38) and Widusa (resistant to races 38, 65, 73, 102, and 449). Molecular marker analyses were carried out in the corresponding $\mathrm{F}_{2}$ individuals in order to identify the genes for anthracnose resistance present in these two differential cultivars. The results of the combined segregation indicate that the resistance to anthracnose races 19,31 , and 38 , present in Mexico 222, is conferred by single dominant race-specific genes organized in a cluster located in B4 linkage group, corresponding to the previously described $\mathrm{Co}-3 / \mathrm{Co}-9$ locus. The resistance to anthracnose races $65,73,102$, and 449 , present in Widusa, is conferred by a dominant gene (or genes) representing a different haplotype of the same $\mathrm{Co}-3 / \mathrm{Co}-9$ cluster. A single dominant gene located in a position independent from cluster $\mathrm{Co}-3 / \mathrm{Co}-9$ (probably at the $\mathrm{Co}-1$ locus) confers specific resistance to race 38 in Widusa. Recombinants for closely linked resistance specificities belonging to the $\mathrm{Co}-3 / \mathrm{Co}-9$ cluster have been detected. The possibility of pyramiding race-specific resistance genes by
\end{abstract}

Communicated by F. J. Muehlbauer.

C. Rodríguez-Suárez and J.J. Ferreira equally share for authorship.

C. Rodríguez-Suárez $\cdot$ A. Pañeda $\cdot$ R. Giraldez $(\bowtie)$

Department of Biología Funcional, University of Oviedo,

33006 Oviedo, Spain

e-mail: giraldez@uniovi.es

J. J. Ferreira · A. Campa

Area de Cultivos Hortofrutícolas y Forestales, SERIDA,

Apdo. 13, 33300 Villaviciosa (Asturias), Spain means of intra-cluster recombination, and its potential use in plant breeding, is indicated.

\section{Introduction}

Anthracnose is the most serious disease worldwide of common bean (Phaseolus vulgaris L.) due to its seed-borne nature and to the pathogenic variability of its causal agent, Colletotrichum lindemuthianum. It causes severe economic losses in tropical, subtropical, and even temperate areas when favorable conditions for the fungus are present during the growing season (Pastor-Corrales and Tu 1994). More than 100 different races of the pathogen have been described (Rodríguez-Guerra et al. 2003). Currently, the different $C$. lindemuthianum races are characterized based on their phenotypic reaction on an anthracnose differential set formed by the 12 differential cultivars, Michelite, Michigan Dark Red Kidney (MDRK), Perry Marrow, Cornell 49242, Widusa, Kaboon, Mexico 222, PI 207262, TO, TU, AB 136, and G2333, and named on the basis of a binary nomenclature system (Pastor-Corrales 1991).

Several genes, conferring dominant resistance to anthracnose, have been described and mapped to different linkage groups of the bean genome. Most of these genes are represented on the differential cultivars: The Co- 1 gene, mapped to linkage group B1, was described in the differential cultivar MDRK (Young and Kelly 1997), and three alleles of this gene were identified in the differential cultivars Perry Marrow, Kaboon, and Widusa, respectively (Melotto and Kelly 2000; Gonçalves-Vidigal and Kelly 2006). The $\mathrm{Co}-2$ gene is represented in the differential cultivar Cornell 49242 and was mapped to linkage group B11 (Freyre et al. 1998). The differential cultivars Mexico 222 and PI 207262 harbor the Co-3/Co-9 gene, mapped to 
linkage group B4 (Geffroy et al. 1999; Méndez-Vigo et al. 2005). Three different alleles of the Co-4 gene, mapped to linkage group B8 (Melotto et al. 2004), have been reported as being present in the differential cultivars TO (Fouilloux 1976), G2333 (Young et al. 1998) and PI 207262 (AlzateMarin et al. 2001), respectively. The Co-5 gene was identified in the differential cultivars TU (Fouilloux 1976) and G2333 (Young and Kelly 1996; Young et al. 1998) and was mapped to linkage group B7 (Campa et al. 2005). Finally, the $C o-6$ gene was described in the differential cultivar $\mathrm{AB}$ 136 and mapped to linkage group B7 (Schwartz et al. 1982; Young and Kelly 1996).

Even though the differential cultivars are used as an international reference, the anthracnose resistance systems of some of them remain unclear. These are the cases of the differential cultivars Widusa and Mexico 222. Allelism tests have been performed to identify the genes present in Widusa (Alzate-Marin et al. 2002; Ferreira et al. 2003; Gonçalves-Vidigal and Kelly 2006) and in Mexico 222 (Méndez-Vigo et al. 2005), but no attempts for mapping of resistances present in these two differential cultivars have been carried out.

Recent genetic analyses of joint segregations for resistance to different anthracnose races (Rodríguez-Suárez et al. 2007) indicated that $\mathrm{Co}-2$ and $\mathrm{Co}-3 / \mathrm{Co}-9$ genes, previously described as single major genes conferring resistance to several races, are organized as clusters of individual genes conferring race-specific resistance. This is in agreement with the cluster organization of families of resistance gene analogue sequences (RGAs) and/or resistance gene candidates (RGCs) mapping close to loci Co-2 (Geffroy et al. 1998; Creusot et al. 1999), Co-4 (Melotto and Kelly 2001; Melotto et al. 2004) and Co-3/Co-9 (Geffroy et al. 1999; Ferrier-Cana et al. 2003, 2005), as well as with the clusters of resistance genes to different pathogens or to different races of the same pathogen that have been described in many plant species (Michelmore and Meyers 1998).

The main objectives of this work were the characterization and mapping of the genes for specific resistance against seven races of anthracnose present in the differential cultivars Widusa and Mexico 222.

\section{Materials and methods}

\section{Plant material}

Molecular marker analyses were carried out using DNA extracted from $103 \mathrm{~F}_{2}$ plants derived from the cross between the two anthracnose differential cultivars Widusa and Mexico 222. $\mathrm{F}_{3}$ families (obtained by selfing individual $F_{2}$ plants) were used to characterize the corresponding $F_{2}$ plants for resistance to seven races of anthracnose (races
$19,31,38,65,73,102$, and 449). In some cases, $F_{4}$ families were obtained in order to confirm the genotype assigned to the corresponding $\mathrm{F}_{3}$ families. The resistance to each race was independently evaluated in $10-40$ plants per $F_{3}$ or $F_{4}$ family. The remaining ten common bean anthracnose differential cultivars (Pastor-Corrales 1991) were used to confirm the identity of the $C$. lindemuthianum isolates.

Inoculation procedure and disease scoring

Seven different races of $C$. lindemuthianum were used: races $31,65,73$, and 449 , from the collection of the Crop and Soil Sciences Department (Michigan State University, USA), and races 19, 38, and 102, from the collection of the SERIDA (Villaviciosa, Asturias, Spain). Isolates of each race were obtained from monosporic cultures maintained in fungus-colonized filter paper at $-20^{\circ} \mathrm{C}$ for long-term storage. The identity of each isolate was confirmed with the anthracnose differential set (Pastor-Corrales 1991). To obtain abundant sporulation, all races were grown at 19$21^{\circ} \mathrm{C}$ in darkness for about 10 days in Potato Dextrose Agar (Difco) (races 19, 31, 38, 65, 102, and 449) or in Marthur's agar (Marthur et al. 1950) (race 73). Spore suspensions were prepared by flooding the plates with $5 \mathrm{ml}$ of $0.01 \%$ Tween 20 (Sigma) in sterile distilled water and scraping the surface of the culture with a spatula. Differential cultivars, and $\mathrm{F}_{3}$ families, were inoculated with a spore suspension of $1.2 \times 10^{6} \mathrm{spores} / \mathrm{ml}$ of the pathogen. Inoculations were carried out on 8-10 day-old seedlings in a climate chamber. The seedlings were sprayed with the aqueous conidial suspension and maintained at $20-22^{\circ} \mathrm{C}, 95-100 \%$ humidity, and $12 \mathrm{~h}$ photoperiod. The responses of the plants were evaluated after 7-9 days using a 1-9 scale where one is no visible symptoms and nine very severely diseased or dead (Van Schoonhoven and Pastor-Corrales 1987).

DNA extraction, PCR amplification and electrophoresis

Genomic DNA from Mexico 222, from Widusa and from the $F_{2}$ progeny derived from the cross Widusa $\times$ Mexico 222 , was isolated from lyophilized young leaves using the Nucleon ${ }^{\mathrm{TM}}$ PhytoPure ${ }^{\mathrm{TM}}$ Genomic DNA Extraction Kit (Amersham Biosciences) following the supplier's instructions.

The following three molecular markers were used: the SCAR marker, SW12, linked to the BGMV resistance gene, bgm-1 (Miklas et al. 2000) and to the anthracnose resistance gene, Co-3/Co-9 (Méndez-Vigo et al. 2005; Rodríguez-Suárez et al. 2007), the RAPD marker, OAH18, linked to the anthracnose-resistance gene $\mathrm{Co}-3 / \mathrm{Co}-9$ (Méndez-Vigo et al. 2005; Rodríguez-Suárez et al. 2007), and the SSR marker PV-ctt001, previously mapped to linkage group B4 (Yu et al. 2000). The amplifications of 
SW12 and OAH18 were carried out as described by Méndez-Vigo et al. (2005). The amplification of PV-ctt001 was carried out according to Yu et al. (2000).

PCR products amplified with SW12 and OAH18 primers were resolved on $2 \%$ agarose gels, stained with ethidium bromide and visualized under UV light. PCR products amplified with PV-ctt001 primers were resolved on $6 \%$ polyacrylamide gels, silver stained and were visualized in white light.

Statistical and linkage analysis

Chi-square was used to test goodness-of-fit of observed to expected ratios in the $\mathrm{F}_{2}$ population Widusa $\times$ Mexico 222 . The segregation analysis of the markers and the resistance genes was performed using MAPMAKER Macintosh version 2.0 (Lander et al. 1987). Distances between ordered loci $(\mathrm{cM})$ were calculated using the Kosambi mapping function.

\section{Results}

Segregations of anthracnose resistance specificities

Parental line Widusa was resistant to races $38,65,73,102$, and 449 of $C$. lindemuthianum, whereas parental line Mexico 222 was resistant to races 19,31 , and 38 .

For all races, $\mathrm{F}_{3}$ families were classified as having all individuals resistant $(\mathrm{R})$, individuals resistant and susceptible (R/S), and all individuals susceptible (S). Table 1 shows the segregations of $\mathrm{F}_{3}$ families for resistance to races 19 , $31,38,65,73,102$, and 449 . Segregations for resistance to races $19,31,65,73,102$, and 449 showed a good fit to the expected ratio for a single dominant gene (1 R: $2 \mathrm{R} / \mathrm{S}: 1 \mathrm{~S})$. Segregations of resistance to race 38 showed a good fit to the expected ratio for two independent dominant genes (7 R: 8 R/S: $1 \mathrm{~S}$ ).

\section{Molecular-marker analyses}

Using the primer corresponding to the SSR marker PVctt001, a fragment of $170 \mathrm{bp}$ was amplified in Widusa and a fragment of $165 \mathrm{bp}$ was amplified in Mexico 222. The primer corresponding to the RAPD marker OAH18 amplified a fragment of $600 \mathrm{bp}$ in Widusa and a fragment of 1,100 bp in Mexico 222. The two markers, PV-ctt001, and OAH18, behaved as codominant loci. Using the primer corresponding to the SCAR marker SW12 no amplification was obtained in Widusa, whereas two different fragments of 700 and $425 \mathrm{bp}$, respectively, were amplified in Mexico 222. Recombinant $F_{2}$ individuals (showing amplification of only one of these fragments) were found, and the two
Table 1 Segregation for resistance to races 19, 31, 38, 65, 73, 102, and 449 of Colletotrichum lindemuthianum in $\mathrm{F}_{3}$ Widusa $\times$ Mexico 222 families

\begin{tabular}{|c|c|c|c|c|c|c|c|c|}
\hline \multirow[t]{2}{*}{ Race } & \multicolumn{3}{|c|}{$\begin{array}{l}\text { Observed } \\
\text { frequency }^{\mathrm{a}}\end{array}$} & \multicolumn{3}{|c|}{$\begin{array}{l}\text { Expected } \\
\text { frequency }\end{array}$} & \multirow[t]{2}{*}{$\chi^{2}$} & \multirow[t]{2}{*}{ Probability } \\
\hline & $\mathrm{R}$ & $\mathrm{R} / \mathrm{S}$ & $\mathrm{S}$ & $\mathrm{R}$ & $\mathrm{R} / \mathrm{S}$ & $S$ & & \\
\hline 19 & 29 & 51 & 18 & 24.5 & 49.0 & 24.5 & 2.63 & 0.27 \\
\hline 31 & 26 & 49 & 20 & 23.8 & 47.5 & 23.8 & 0.85 & 0.65 \\
\hline 38 & 34 & 33 & 5 & 31.5 & 36.0 & 4.5 & 0.50 & 0.78 \\
\hline 65 & 19 & 52 & 28 & 24.8 & 49.5 & 24.8 & 1.89 & 0.39 \\
\hline 73 & 19 & 52 & 28 & 24.8 & 49.5 & 24.8 & 1.89 & 0.39 \\
\hline 102 & 20 & 54 & 28 & 25.5 & 51.0 & 25.5 & 1.61 & 0.45 \\
\hline 449 & 18 & 52 & 27 & 24.3 & 48.5 & 24.3 & 2.18 & 0.34 \\
\hline
\end{tabular}

${ }^{\mathrm{a}} \mathrm{F}_{3}$ families were classified as having all individuals resistant (R), individuals resistant and susceptible (R/S), and all individuals susceptible (S)

${ }^{\mathrm{b}}$ For races 19, 31, 65, 73, 102, and 449 the expected ratio was 1:2:1 (one dominant gene) and for race 38 the expected ratio was 7:8:1 (two independent dominant genes)

fragments were considered as belonging to different loci (SW12 ${ }_{700}$ and $\mathrm{SW} 12_{425}$, respectively). Table 2 shows the segregations for the molecular marker loci PV-ctt001, OAH18, SW $12_{700}$, and SW12 ${ }_{425}$, in the Widusa $\times$ Mexico $222 \mathrm{~F}_{2}$ population. A good fit to the expected ratio for a single gene was obtained in all cases.

Linkage analysis

Table 3 shows the joint segregation for resistance to anthracnose races $19,31,65,73,102$, and 449 , in $F_{3}$ Widusa $\times$ Mexico 222 families, and for molecular marker loci PV-ctt001, OAH18, SW12 ${ }_{700}$, and SW12 ${ }_{425}$ in the corresponding $\mathrm{F}_{2}$ plants. Recombination between resistance specificities was observed only in two $\mathrm{F}_{3}$ families. In these families, the number of individuals scored for resistance to some races was increased in order to reduce the possibility of error. Table 4 shows the segregation for resistance to races $19,31,65,73,102$, and 449 , within these two recombinant $\mathrm{F}_{3}$ families $\left(\mathrm{F}_{3}-94\right.$ and $\left.\mathrm{F}_{3}-98\right)$. Resistances to races 19 (proceeding from Mexico 222) and 102 (proceeding from Widusa) were tested in the progenies ( $\mathrm{F}_{4}$ families) of seven individuals belonging to the $\mathrm{F}_{3}-94$ family. Three of these $\mathrm{F}_{4}$ families were homozygous resistant for both races, confirming their intra-cluster recombination origin. In sum, the results shown in Table 3 can be explained with a minimum of three closely linked resistance genes arranged in a cluster located in linkage group B4. Figure 1 shows a genetic map including all resistance specificities and molecular markers appearing in Table 3.

Given the previously deduced existence of two independent dominant genes conferring resistance to race 38 
Table 2 Segregation for molecular marker loci PV-ctt001, OAH18, SW12 700 , and SW12 ${ }_{425}$, in the Widusa $\times$ Mexico $222 \mathrm{~F}_{2}$ population

\begin{tabular}{|c|c|c|c|c|c|c|c|c|}
\hline \multirow[t]{2}{*}{$\overline{\text { Locus }}$} & \multicolumn{3}{|c|}{ Observed frequency $^{\mathrm{a}}$} & \multicolumn{3}{|c|}{ Expected frequency $^{\mathrm{b}}$} & \multirow[t]{2}{*}{$\chi^{2}$} & \multirow[t]{2}{*}{ Probability } \\
\hline & $\mathrm{W} / \mathrm{W}$ & $\mathrm{W} / \mathrm{M}$ & $\mathrm{M} / \mathrm{M}$ & $\mathrm{W} / \mathrm{W}$ & $\mathrm{W} / \mathrm{M}$ & $\mathrm{M} / \mathrm{M}$ & & \\
\hline PV-ctt001 & 21 & 55 & 27 & 25.75 & 51.50 & 25.75 & 1.17 & 0.56 \\
\hline OAH18 & 21 & 54 & 28 & 25.75 & 51.50 & 25.75 & 1.19 & 0.55 \\
\hline SW $12_{700}$ & 22 & 81 & & 25.75 & 77.25 & & 0.73 & 0.39 \\
\hline SW $12_{425}$ & 23 & 80 & & 25.75 & 77.25 & & 0.39 & 0.53 \\
\hline
\end{tabular}

${ }^{a}$ W/W homozygous for Widusa alleles; M/M homozygous for Mexico 222 alleles; W/M heterozygous

${ }^{\mathrm{b}}$ For loci PV-ctt001 and OAH18 (codominant) the expected ratio was 1:2:1, and for loci SW12 ${ }_{700}$ and SW12 ${ }_{425}$ (dominant) the expected ratio was $1: 3$

Table 3 Joint segregation for resistance to races 19, 31, 65, 73, 102, and 449 of Colletotrichum lindemuthianum in $\mathrm{F}_{3}$ Widusa $\times$ Mexico 222 families, and for molecular marker loci PV-ctt001, OAH18, SW12 700 , and SW12 ${ }_{425}$ in the corresponding $\mathrm{F}_{2}$ plants

\begin{tabular}{|c|c|c|c|c|c|c|c|c|c|c|}
\hline \multicolumn{6}{|c|}{ Resistance spectrum of $\mathrm{F}_{3}$ families ${ }^{\mathrm{a}}$} & \multicolumn{4}{|c|}{ Genotype of molecular marker loci of F2 plants $^{\mathrm{b}}$} & \multirow[t]{2}{*}{ Frequency } \\
\hline Race 19 & Race 31 & Race 65 & Race 73 & Race 102 & Race 449 & PV-ctt001 & OAH18 & SW $12_{700}$ & $\mathrm{SW} 12_{425}$ & \\
\hline$S$ & $\mathrm{~S}$ & $\mathrm{R}$ & $\mathrm{R}$ & $\mathrm{R}$ & $\mathrm{R}$ & $\mathrm{W} / \mathrm{W}$ & $\mathrm{W} / \mathrm{W}$ & $\mathrm{W} / \mathrm{W}$ & $\mathrm{W} / \mathrm{W}$ & 14 \\
\hline$S$ & $\mathrm{~S}$ & $\mathrm{R}$ & $\mathrm{R}$ & $\mathrm{R}$ & $\mathrm{R}$ & $\mathrm{W} / \mathrm{W}$ & $\mathrm{W} / \mathrm{W}$ & $\mathrm{W} / \mathrm{W}$ & $\mathrm{M} /-$ & 1 \\
\hline$S$ & $\mathrm{~S}$ & $\mathrm{R}$ & $\mathrm{R}$ & $\mathrm{R}$ & $\mathrm{R}$ & $\mathrm{W} / \mathrm{W}$ & $\mathrm{W} / \mathrm{M}$ & $\mathrm{W} / \mathrm{W}$ & $\mathrm{W} / \mathrm{W}$ & 1 \\
\hline $\mathrm{R}$ & $\mathrm{R}$ & $\mathrm{S}$ & $S$ & $\mathrm{~S}$ & $\mathrm{~S}$ & $\mathrm{M} / \mathrm{M}$ & $\mathrm{M} / \mathrm{M}$ & $\mathrm{M} /-$ & $\mathrm{M} /-$ & 19 \\
\hline $\mathrm{R}$ & $\mathrm{R}$ & $\mathrm{S}$ & $\mathrm{S}$ & $\mathrm{S}$ & $\mathrm{S}$ & $\mathrm{M} / \mathrm{M}$ & $\mathrm{W} / \mathrm{M}$ & $\mathrm{M} /-$ & $\mathrm{M} /-$ & 1 \\
\hline $\mathrm{R}$ & $\mathrm{R}$ & $\mathrm{S}$ & $\mathrm{S}$ & $\mathrm{S}$ & $\mathrm{S}$ & $\mathrm{W} / \mathrm{M}$ & $\mathrm{W} / \mathrm{M}$ & M/- & M/- & 2 \\
\hline $\mathrm{R} / \mathrm{S}$ & $\mathrm{R} / \mathrm{S}$ & $\mathrm{R} / \mathrm{S}$ & $\mathrm{R} / \mathrm{S}$ & $\mathrm{R} / \mathrm{S}$ & $\mathrm{R} / \mathrm{S}$ & W/M & W/M & M/- & M/- & 39 \\
\hline $\mathrm{R} / \mathrm{S}$ & $\mathrm{R} / \mathrm{S}$ & $\mathrm{R} / \mathrm{S}$ & $\mathrm{R} / \mathrm{S}$ & $\mathrm{R} / \mathrm{S}$ & $\mathrm{R} / \mathrm{S}$ & W/M & W/M & $\mathrm{M} /-$ & W/W & 2 \\
\hline $\mathrm{R} / \mathrm{S}$ & $\mathrm{R} / \mathrm{S}$ & $\mathrm{R} / \mathrm{S}$ & $\mathrm{R} / \mathrm{S}$ & $\mathrm{R} / \mathrm{S}$ & $\mathrm{R} / \mathrm{S}$ & W/M & $\mathrm{M} / \mathrm{M}$ & M/- & $\mathrm{M} /-$ & 2 \\
\hline $\mathrm{R} / \mathrm{S}$ & $\mathrm{R} / \mathrm{S}$ & $\mathrm{R} / \mathrm{S}$ & $\mathrm{R} / \mathrm{S}$ & $\mathrm{R} / \mathrm{S}$ & $\mathrm{R} / \mathrm{S}$ & W/W & $\mathrm{W} / \mathrm{W}$ & W/W & $\mathrm{W} / \mathrm{W}$ & 1 \\
\hline $\mathrm{R} / \mathrm{S}$ & $\mathrm{R} / \mathrm{S}$ & $\mathrm{R} / \mathrm{S}$ & $\mathrm{R} / \mathrm{S}$ & $\mathrm{R} / \mathrm{S}$ & $\mathrm{R} / \mathrm{S}$ & $\mathrm{W} / \mathrm{M}$ & $\mathrm{W} / \mathrm{W}$ & M/- & $\mathrm{M} /-$ & 1 \\
\hline $\mathrm{R}$ & $\mathrm{R} / \mathrm{S}$ & $\mathrm{R} / \mathrm{S}$ & $\mathrm{R} / \mathrm{S}$ & $\mathrm{R} / \mathrm{S}$ & $\mathrm{R} / \mathrm{S}$ & $\mathrm{W} / \mathrm{M}$ & W/M & $\mathrm{M} /-$ & M/- & $1^{\mathrm{c}}$ \\
\hline $\mathrm{R} / \mathrm{S}$ & $\mathrm{S}$ & $\mathrm{R} / \mathrm{S}$ & $\mathrm{R} / \mathrm{S}$ & $\mathrm{R} / \mathrm{S}$ & $\mathrm{R} / \mathrm{S}$ & $\mathrm{W} / \mathrm{M}$ & $\mathrm{W} / \mathrm{M}$ & $\mathrm{W} / \mathrm{W}$ & W/W & $1^{\mathrm{c}}$ \\
\hline
\end{tabular}

${ }^{a} \mathrm{~F}_{3}$ families were classified for each race as having all individuals resistant (R), individuals resistant and susceptible (R/S), and all individuals susceptible (S)

${ }^{\mathrm{b}} \mathrm{W} / \mathrm{W}$ homozygous for the Widusa allele; W/- homozygous for the Widusa allele or heterozygous; M/M homozygous for the Mexico 222 allele; M/- homozygous for the Mexico 222 allele or heterozygous; W/M heterozygous

${ }^{\mathrm{c}}$ Individuals showing evidence of recombination between resistance specificities

(Table 1), one of them proceeding from Widusa and the other from Mexico 222, the possibility of one of these genes being located in the cluster including the other resistance specificities can be considered. Table 5 shows the joint segregation for resistance to races 19, 31, 65, 73, 102, 449 , and 38, compared to the expected frequencies under the assumption that the resistance gene to race 38 proceeding from Mexico 222 is the one located in the cluster. Differences between the observed and expected frequencies are not significant.

\section{Discussion}

Concerning Mexico 222, the results obtained indicate that its resistance to anthracnose races 19,31 , and 38 , is conferred by single dominant race-specific genes organized in a cluster located in B4 linkage group, closely linked to molecular markers OAH18, SW12, and PV-ctt001. This cluster probably corresponds to the $\mathrm{Co}-3$ gene. The anthracnose resistance present in the genotype Mexico 222 was first studied by Bannerot (1965), the Co-3 resistance gene, originally known as Mexique 1, being later described in this genotype (Bannerot et al. 1971). The resistance to race 31 (Kappa, Ebnet) present in Mexico 222 was analyzed by Fouilloux (1976) and assumed to be conferred by the Co-3 (Mexique 1) gene. The cluster revealed in this work also corresponds to the $\mathrm{Co}-9$ gene, first described and located in B4 linkage group by Geffroy et al. (1999) in the genotype BAT 93, and later mapped between the markers OAH18 and SW12 (Méndez-Vigo et al. 2005), using a $F_{2}$ population proceeding from a cross including the genotype A493 
Table 4 Segregation for resistance to races 19, 31, 65, 73, 102, and 449 within the two $F_{3}$ families proceeding from the cross Widusa $\times$ Mexico 222 that showed evidence of recombination

\begin{tabular}{|c|c|c|c|c|}
\hline \multirow[t]{3}{*}{ Race } & \multicolumn{4}{|c|}{$\mathrm{F}_{3}$ Families } \\
\hline & \multicolumn{2}{|c|}{$\mathrm{F}_{3}-94$} & \multicolumn{2}{|c|}{$\mathrm{F}_{3}-98$} \\
\hline & $\mathrm{R}$ & $\mathrm{S}$ & $\mathrm{R}$ & $\mathrm{S}$ \\
\hline 19 & 37 & 0 & 11 & 5 \\
\hline 31 & 7 & 2 & 0 & 20 \\
\hline 65 & 26 & 4 & 6 & 4 \\
\hline 73 & 7 & 2 & 5 & 5 \\
\hline 102 & 22 & 3 & 15 & 2 \\
\hline 449 & 8 & 1 & 9 & 1 \\
\hline
\end{tabular}

$R$ resistant individuals, $S$ susceptible individuals

(Alubia/BAT 93). The results obtained here confirm the allelism between $\mathrm{Co}-3$ and $\mathrm{Co}-9$, found by Méndez-Vigo et al. (2005) using race 38.

Concerning Widusa, the results obtained indicate that its resistance to anthracnose races $65,73,102$, and 449 , is conferred by a dominant gene (or genes) representing a different haplotype of the same $\mathrm{Co}-3 / \mathrm{Co}-9$ cluster. In this material, specific resistance to race 38 is conferred by a single dominant gene located in a position independent from cluster $\mathrm{Co}-3 / \mathrm{Co}-9$. The presence of two different anthracnose-resistance genes in Widusa, one of them conferring resistance to race beta $\left(D_{10}\right)$ and the other conferring resistance to races beta and gamma $\left(D_{10}+E_{8} b\right)$, was first indicated by Bannerot (1965). The correspondence between the gene conferring resistance to race 65 in Widusa and $\mathrm{Co}-3 /$ Co-9, demonstrated in the current work, agrees with

Table 5 Joint segregation of $\mathrm{F}_{3}$ Widusa $\times$ Mexico 222 families for resistance to C. lindemuthianum races $19,31,65,73,102,449$ and 38 , compared to the expected frequencies under the assumption of two dominant genes being responsible for the resistance to race 38; one of
Alzate-Marin et al. (2007) who proposed the presence of an allele of the $C o-9$ gene in Widusa from the observed lack of segregation, using race 65 , in two $\mathrm{F}_{2}$ populations derived from the crosses Widusa $\times$ BAT 93 and Widusa $\times$ PI 207262, respectively. The combined results of different allelism tests support the hypothesis that the anthracnosedifferential cultivar PI 207262 carries resistance genes in clusters $\mathrm{Co}-4$ and $\mathrm{Co}-3 / \mathrm{Co}-9$ (Alzate-Marin et al. 2007). As BAT 93 was derived from PI 207262, it is assumed that these two genotypes share the same $\mathrm{Co}-3 / \mathrm{Co}-9$ haplotype. Concerning the resistance to race 73 , Gonçalves-Vidigal and Kelly (2006) using this race, found a segregation ratio of 63 resistant: 1 susceptible in a $F_{2}$ population derived from the cross Widusa $\times$ PI 207262, and a segregation ratio of 15 resistant: 1 susceptible in a $F_{2}$ population derived from the cross Widusa $\times$ BAT 93. Assuming that PI 207262 carries two resistance genes to race 73 , located in clusters $\mathrm{Co}-4$ and $\mathrm{Co}-3 / \mathrm{Co}-9$, respectively, and that BAT 93 carries one resistance gene to race 73 , located in cluster $\mathrm{Co}-3 / \mathrm{Co}-9$, they concluded that the $\mathrm{Co}-3 / \mathrm{Co}-9$ cluster is not involved in the resistance to race 73 in Widusa. From the results of the current work concerning linkage between resistance genes and molecular markers (Table 3; Fig. 1), it can unequivocally be concluded that the gene conferring resistance to race 73 in Widusa is included in the $\mathrm{Co}-3 / \mathrm{Co}-9$ cluster. Then, the results of the allelism tests conducted by Gonçalves-Vidigal and Kelly (2006) would indicate that a second locus, different from $\mathrm{Co}-3 / \mathrm{Co}-9$, confers resistance to race 73 in BAT 93, and a third locus, different from Co-4 and from $\mathrm{Co}-3 / \mathrm{Co}-9$, confers resistance to race 73 in PI 207262. Recently, Geffroy et al. (2007) demonstrated the presence in the genotype BAT 93 of two anthracnose resistance loci,

them, proceeding from Mexico 222, located in the cluster including the genes conferring resistance to the other races, and the other, proceeding from Widusa, not linked to this cluster

\begin{tabular}{|c|c|c|c|c|c|c|c|c|}
\hline \multicolumn{7}{|c|}{ Resistance spectrum of $\mathrm{F}_{3}$ families ${ }^{\mathrm{a}}$} & \multirow{2}{*}{$\begin{array}{l}\text { Observed } \\
\text { frequency }\end{array}$} & \multirow{2}{*}{$\begin{array}{l}\text { Expected } \\
\text { frequency }\end{array}$} \\
\hline Race 19 & Race 31 & Race 65 & Race 73 & Race 102 & Race 449 & Race 38 & & \\
\hline $\mathrm{R}$ & $\mathrm{R}$ & $\mathrm{S}$ & $\mathrm{S}$ & $\mathrm{S}$ & $\mathrm{S}$ & $\mathrm{R}$ & 21 & $18.0(4 / 16)$ \\
\hline $\mathrm{R}$ & $\mathrm{R}$ & $\mathrm{S}$ & $\mathrm{S}$ & $\mathrm{S}$ & $\mathrm{S}$ & $\mathrm{R} / \mathrm{S}$ & 0 & 0 \\
\hline $\mathrm{R}$ & $\mathrm{R}$ & $\mathrm{S}$ & $\mathrm{S}$ & $\mathrm{S}$ & $\mathrm{S}$ & $\mathrm{S}$ & 0 & 0 \\
\hline $\mathrm{S}$ & $\mathrm{S}$ & $\mathrm{R}$ & $\mathrm{R}$ & $\mathrm{R}$ & $\mathrm{R}$ & $\mathrm{R}$ & 2 & $4.5(1 / 16)$ \\
\hline $\mathrm{S}$ & $\mathrm{S}$ & $\mathrm{R}$ & $\mathrm{R}$ & $\mathrm{R}$ & $\mathrm{R}$ & $\mathrm{R} / \mathrm{S}$ & 7 & $9.0(2 / 16)$ \\
\hline $\mathrm{S}$ & $\mathrm{S}$ & $\mathrm{R}$ & $\mathrm{R}$ & $\mathrm{R}$ & $\mathrm{R}$ & $\mathrm{S}$ & 5 & $4.5(1 / 16)$ \\
\hline $\mathrm{R} / \mathrm{S}$ & $\mathrm{R} / \mathrm{S}$ & $\mathrm{R} / \mathrm{S}$ & $\mathrm{R} / \mathrm{S}$ & $\mathrm{R} / \mathrm{S}$ & $\mathrm{R} / \mathrm{S}$ & $\mathrm{R}$ & 11 & $9.0(2 / 16)$ \\
\hline $\mathrm{R} / \mathrm{S}$ & $\mathrm{R} / \mathrm{S}$ & $\mathrm{R} / \mathrm{S}$ & $\mathrm{R} / \mathrm{S}$ & $\mathrm{R} / \mathrm{S}$ & $\mathrm{R} / \mathrm{S}$ & $\mathrm{R} / \mathrm{S}$ & 26 & $27.0(6 / 16)$ \\
\hline \multirow[t]{2}{*}{$\mathrm{R} / \mathrm{S}$} & $\mathrm{R} / \mathrm{S}$ & $\mathrm{R} / \mathrm{S}$ & $\mathrm{R} / \mathrm{S}$ & $\mathrm{R} / \mathrm{S}$ & $\mathrm{R} / \mathrm{S}$ & $\mathrm{S}$ & 0 & 0 \\
\hline & & & & & & & \multicolumn{2}{|c|}{$\chi^{2}=2.87(p=0.72)$} \\
\hline
\end{tabular}

In this assumption, intra-cluster recombination has not been considered

${ }^{\mathrm{a}} \mathrm{F}_{3}$ families were classified for each race as having all individuals resistant (R), individuals resistant and susceptible (R/S), and all individuals susceptible (S) 


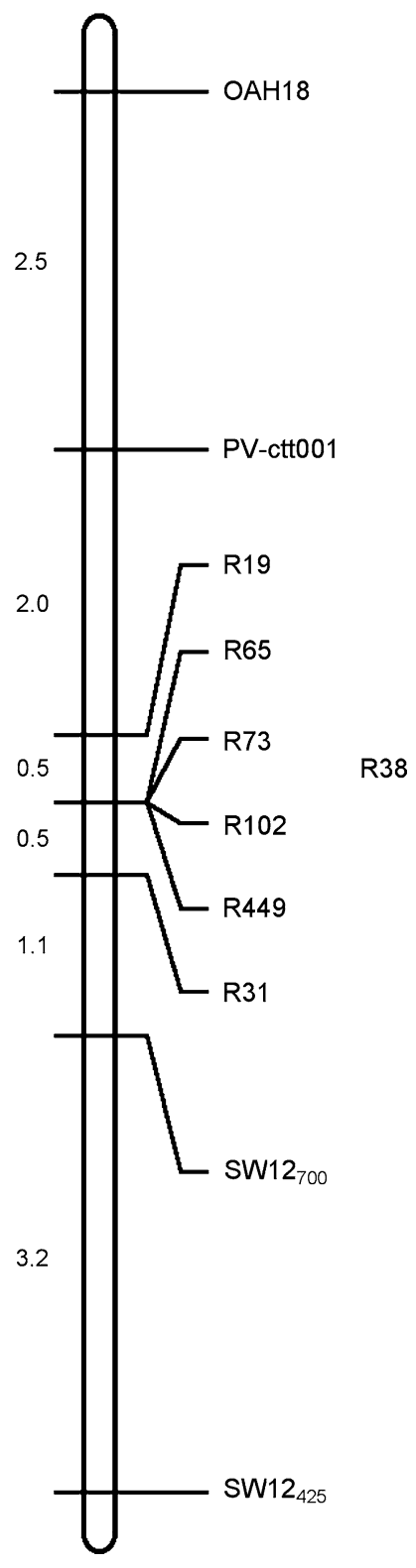

Fig. 1 Relative positions of markers OAH18, PV-ctt001, SW12 700 , and SW12 ${ }_{425}$, and the genes conferring resistance to races 19 (R19), 31 (R31), 65 (R65), 73 (R73), 102 (R102), and 449 (R449), included in the $\mathrm{Co}-3 / \mathrm{Co}-9$ cluster. The relative position of the gene conferring resistance to race 38 in Mexico 222 (R38) is undetermined. Map distances, on the left, are expressed in centiMorgans, estimated using the Kosambi mapping function

located in linkage groups B4 (Co-3/Co-9) and B2 (Co-u), respectively. Alzate-Marin et al. (2007) using race 23, found a 63:1 segregation ratio, corresponding to three independent dominant genes, in a $\mathrm{F}_{2}$ population derived from the cross PI $207262 \times$ Mexico 222. They assumed that PI 207262 carries only the two resistance genes $\mathrm{Co}-4$ and $\mathrm{Co}$ $3 / \mathrm{Co}-9$, and concluded that the resistance to race 23 present in Mexico 222 should be conferred by a gene different from Co-3/Co-9. There are some evidences indicating that Mexico 222 possesses two genes conferring resistance against race 7 (unpublished data, cited by Kelly and Vallejo 2004). The existence of a third resistance locus in PI 207262 conferring resistance to race 23 could be an alternative explanation.

The results of the current work concerning resistance to race 38 in Widusa differ from those obtained in a previous allelism study involving resistance to race 38 (Ferreira et al. 2003), in which 13 resistant:3 susceptible ratio was observed in a $F_{2}$ population proceeding from a cross between Widusa (resistant) and Xana (susceptible). This was interpreted under the assumption of two independent genes, one dominant and the other recessive, being present in Widusa. In that study, the segregation ratios observed in the $\mathrm{F}_{2}$ populations from crosses between Widusa and other materials carrying a single dominant gene conferring resistance to race 38 (PI 207262, A1183, Mexico 222, and TU), showed a good fit to the expected values under the hypothesis of three genes, two dominant and one recessive, being involved (61:3). However, the reexamination of these data indicates that they show also a good fit to the expected values under the hypothesis of two dominant genes (a single dominant gene in each parent) being involved (15:1). The excess of resistant $F_{2}$ individuals proceeding from the cross Widusa $\times$ Xana observed by Ferreira et al. (2003), if not artifactual, could be due to gene interaction affecting resistance to race 38 in this specific cross. Although recessive resistance to anthracnose has been reported in other cases in the literature (Cardenas et al. 1964; Muhalet et al. 1981), it has not been detected in the current work. GonçalvesVidigal and Kelly (2006), using a race 65 (65b) overcoming BAT 93, different from the one used by Alzate-Marin et al. (2007), and from the one used in the current work, found no segregation in $\mathrm{F}_{2}$ populations derived from the crosses Widusa $\times$ MDRK and Widusa $\times$ Kaboon, concluding that the resistance to race $65 \mathrm{~b}$ present in Widusa is conferred by the $\mathrm{Co}-1$ locus. The resistance-specificity to race 38 present in Widusa could be also located at this locus.

Genes providing resistance to different pathogens as well as to different races of the same pathogen have been reported to be clustered in chromosomal regions in many plant species (Crute and Pink 1996; Vear et al. 1997; Sharma et al. 2004). In a previous work (Rodríguez-Suárez et al. 2007), it was suggested that anthracnose-resistance Co- loci of common bean, previously described as single major gene conferring resistance to several anthracnose races (Kelly and Vallejo 2004), could be organized as clusters of several genes, each giving resistance to one, or at most a few, races. The results obtained in this work confirm this model. The recombination found between resistance specificities (Table 3) indicate that resistance to races 19 and 31 present in Mexico 222 are determined by individual race-specific genes. The absence of recombination found between resistance to races $65,73,102$, and 449 , present in 
Widusa can be explained by a tighter linkage between the individual genes conferring resistance to these races. In this case, the possibility of resistance to more than one race being conferred by a single gene cannot be excluded.

The existence of intra-cluster recombination can be of considerable practical importance. Race-specific resistance genes present in different haplotypes of the same cluster could be pyramided by genetic recombination within the cluster. After accumulation of the resistance specificities, the enhanced new recombinant haplotype could be introgressed into susceptible varieties, practically as a single locus.

Acknowledgments This work was supported by grants AGL20012676-C02-01, RTA02-052-C2-2 and AGL2004-08145-C02-01 from the Ministerio de Ciencia y Tecnología, Spain. Cristina RodríguezSuárez was recipient of a salary fellowship from the Ministerio de Ciencia y Tecnología, Spain. Astrid Pañeda was recipient of salary fellowship from the Fundación para el Fomento de la Investigación Científica y Tecnológica (FICYT), Principado de Asturias, Spain. Ana Campa was recipient of a salary fellowship from the Instituto de Investigación y Tecnología Agraria y Alimentaria (INIA), Spain. Races $31,65,73$, and 449 were kindly provided by James D. Kelly (Michigan State University).

\section{References}

Alzate-Marin AL, Almeida KS, Barros EG, Moreira MA (2001) Preliminary results of allelism studies for anthracnose resistance genes of common bean cultivar PI 207262. Annu Rep Bean Improv Coop 44:113-114

Alzate-Marin AL, Arruda KM, Barros EG, Moreira MA (2002) Allelism studies for anthracnose resistance genes of common bean cultivar Widusa. Annu Rep Bean Improv Coop 45:110-111

Alzate-Marin AL, Souza KA, Morais Silva MG, Oliveira EJ, Moreira MA, Barros EG (2007) Genetic characterization of anthracnose resistance genes $\mathrm{Co}-4^{3}$ and $\mathrm{Co}-9$ in common bean cultivar tlalnepantla 64 (PI 207262). Euphytica 154:1-8

Bannerot H (1965) Résultats de l'infection d'une collection de haricots par six races physiologiques d'anthracnose. Ann Amélior Plantes 15:201-222

Bannerot H, Derieux M, Fouilloux G (1971) Mise en évidence d'un second gène de résistance totale a l'anthracnose chez le haricot. Ann Amélior Plantes 21:83-85

Campa A, Rodríguez-Suárez C, Pañeda A, Giraldez R, Ferreira JJ (2005) The bean anthracnose resistance gene $\mathrm{Co}-5$, is located in linkage group B7. Annu Rep Bean Improv Coop 48:68-69

Cardenas F, Adams MW, Andersen A (1964) The genetic system for reaction of field beans (Phaseolus vulgaris L.) to infection by three physiologic races of Colletotrichum lindemuthianum. Euphytica 13:178-186

Creusot F, Macadré C, Ferrier-Cana E, Riou C, Geffroy V, Sévignac M, Dron M, Langin T (1999) Cloning and molecular characterization of three members of the NBS-LRR subfamily located in the vicinity of the Co-2 locus for anthracnose resistance in Phaseolus vulgaris. Genome 42:254-264

Crute IR, Pink DAC (1996) Genetics and utilization of pathogen resistance in plants. Plant Cell 8:1747-1755

Ferreira JJ, Rodríguez C, Pañeda A, Giraldez R (2003) Allelism test for resistance to race 38 of anthracnose in common bean differential cultivar, Widusa. Annu Rep Bean Improv Coop 46:169-170
Ferrier-Cana E, Geffroy V, Macadré C, Creusot F, Imbert-Bolloré P, Sévignac M, Langin T (2003) Characterization of expressed NBS-LRR resistance gene candidates from common bean. Theor Appl Genet 106:251-261

Ferrier-Cana E, Macadré C, Sévignac M, David P, Langin T, Geffroy V (2005) Distinct post-transcriptional modifications result into seven alternative transcripts of the CC-NBS-LRR gene JA1tr of Phaseolus vulgaris. Theor Appl Genet 110:895-905

Fouilloux G (1976) L'anthracnose du haricot (Colletotrichum lindemuthianum, Sacc et Magn): nouvelles sources de résistance et nouvelles races physiologiques. Ann Amélior Plantes 26:443-453

Freyre R, Skroch PW, Geffroy V, Adam-Blondon A-F, Shirmohamadali A, Johnson WC, Llaca V, Nodari RO, Pereira PA, Tsai S-M, Tohme J, Dron M, Nienhuis J, Vallejos CE, Gepts P (1998) Towards an integrated linkage map of common bean. 4. Development of a core linkage map and alignment of RFLP maps. Theor Appl Genet 97:847-856

Geffroy V, Creusot F, Falquet J, Sévignac M, Adam-Blondon A-F, Bannerot H, Gepts P, Dron M (1998) A family of LRR sequences in the vicinity of the $\mathrm{Co}-2$ locus for anthracnose resistance in Phaseolus vulgaris and its potential use in marker-assisted selection. Theor Appl Genet 96:494-502

Geffroy V, Sicard D, de Oliveira JCF, Sévignac M, Cohen S, Gepts P, Neema C, Langin T, Dron M (1999) Identification of an ancestral resistance gene cluster involved in the coevolution process between Phaseolus vulgaris and its fungal pathogen Colletotrichum lindemuthianum. Mol Plant Microbe Interact 12:774-784

Geffroy V, Sévignac M, Billant P, Dron M, Langin T (2007) Resistance to Colletotrichum lindemuthianum in Phaseolus vulgaris: a case study for mapping two independent genes. Theor Appl Genet [Epub ahead of print]

Gonçalves-Vidigal MC, Kelly JD (2006) Inheritance of anthracnose resistance in the common bean cultivar Widusa. Euphytica 151:411-419

Kelly JD, Vallejo VA (2004) A comprehensive review of the major genes conditioning resistance to anthracnose in common bean. HortScience 39:1196-1207

Lander ES, Green P, Abrahamson J, Barlow A, Daly MJ, Lincoln SE, Newburg L (1987) MAPMAKER: an interactive computer package for constructing primary genetic linkage maps of experimental and natural populations. Genomics 1:174-181

Marthur RS, Barnett HL, Lilly VG (1950) Sporulation of Colletotrichum lindemuthianum in culture. Phytopathology 40:104-114

Melotto M, Kelly JD (2000) An allelic series at the Co- 1 locus conditioning resistance to anthracnose in common bean of Andean origin. Euphytica 116:143-149

Melotto M, Kelly JD (2001) Fine mapping of the Co-4 locus of common bean reveals a resistance gene candidate, $C O K-4$, that encodes for a protein kinase. Theor Appl Genet 103:508517

Melotto M, Coelho MF, Pedrosa-Harand A, Kelly JD, Camargo LEA (2004) The anthracnose resistance locus $\mathrm{Co}-4$ of common bean is located on chromosome 3 and contains putative disease resistance-related genes. Theor Appl Genet 109:690-699

Méndez-Vigo B, Rodríguez-Suárez C, Pañeda A, Ferreira JJ, Giraldez R (2005) Molecular markers and allelic relationships of anthracnose resistance gene cluster B4 in common bean. Euphytica 141:237-245

Michelmore RW, Meyers BC (1998) Clusters of resistance genes in plants evolve by divergent selection and birth-and-death process. Genome Res 8:1113-1130

Miklas PN, Delorme R, Stone V, Daly MJ, Stavely JR, Steadman JR, Bassett MJ, Beaver JS (2000) Bacterial, fungal, and viral disease resistance loci mapped in a recombinant inbred common bean population ('Dorado'/XAN 176). J Am Soc Hort Sci 125:476481 
Muhalet CS, Adams MW, Saettler AW, Ghaderi A (1981) Genetic system for the reaction of field beans to beta, gamma, and delta races of Colletotrichum lindemuthianum. J Am Soc Hort Sci 106:601604

Pastor-Corrales MA (1991) Estandarización de variedades diferenciales y designación de razas de Colletotrichum lindemuthianum. Phytopathology 81:694

Pastor-Corrales MA, Tu JC (1994) Antracnosis. In: Pastor-Corrales MA, Schwartz HF (eds) Problemas de producción del frijol en los trópicos. CIAT, Cali, pp 87-120

Rodríguez-Guerra R, Ramírez-Rueda MT, Martínez de la Vega O, Simpson J (2003) Variation in genotype, pathotype and anastomosis groups of Colletotrichum lindemuthianum isolates from Mexico. Plant Pathol 52:228-235

Rodríguez-Suárez C, Méndez-Vigo B, Pañeda A, Ferreira JJ, Giraldez R (2007) A genetic linkage map of Phaseolus vulgaris L. and localization of genes for specific resistance to six races of anthracnose (Colletotrichum lindemuthianum). Theor Appl Genet 114:713-722

Schwartz HF, Pastor-Corrales MA, Singh SP (1982) New sources of resistance to anthracnose and angular leaf spot of beans (Phaseolus vulgaris L.). Euphytica 31:741-754
Sharma KD, Winter P, Kahl G, Muehlbauer J (2004) Molecular mapping of Fusarium oxysporum f. sp. ciceris race 3 resistance gene in chickpea. Theor Appl Genet 108:1243-1248

Van Schoonhoven A, Pastor-Corrales MA (1987) Standard system for the evaluation of bean germplasm. CIAT, Cali

Vear F, Gentzbittel L, Philippon J, Mouzeyar S, Mestries E, RoeckelDrevet P, Tourvieille de Labrouhe D, Nicolas P (1997) The genetics of resistance to five races of downy mildew (Plasmopara halstedii) in sunflower (Helianthus annuus L.). Theor Appl Genet 95:584-589

Young RA, Kelly JD (1996) Characterization of the genetic resistance to Colletotrichum lindemuthianum in common bean differential cultivars. Plant Dis 80:650-654

Young RA, Kelly JD (1997) RAPD markers linked to three major anthracnose resistance genes in common bean. Crop Sci 37:940 946

Young RA, Melotto M, Nodari RO, Kelly JD (1998) Marker-assisted dissection of the oligogenic anthracnose resistance in the common bean cultivar, 'G2333'. Theor Appl Genet 96:87-94

Yu K, Park SJ, Poysa V, Gepts P (2000) Integration of simple sequence repeat (SSR) markers into a molecular linkage map of common bean (Phaseolus vulgaris L.). J Hered 91:429-434 